\title{
Discursos de professores em formação continuada acerca da relação entre a manipulação genética e a possibilidade de melhoramento em humanos
}

\author{
Teachers' speech in continuing education \\ around the relations between genetic manipulation \\ and the possibility of human improvement
}

\author{
Eduarda Maria Schneider ${ }^{1}$ • Fernanda Aparecida Meglhioratti ${ }^{2}$ • \\ Maria Júlia Corazza ${ }^{3}$
}

\begin{abstract}
Resumo: Novos conhecimentos científicos e tecnológicos da biologia molecular estão cada vez mais presentes na sociedade, tornando-se necessária a educação científica dos cidadãos. Este artigo analisa os discursos de professores sobre a manipulação genética e o melhoramento humano no contexto de um curso de formação continuada sobre o movimento eugênico ocorrido nos séculos 19 e 20. Os dados, coletados por meio de videogravação, foram transcritos e analisados pela metodologia de Análise de Discurso. Os resultados apontam para uma mudança gradual nos posicionamentos dos professores. No início, os sujeitos apresentam uma visão mais determinista ao aludirem que, por meio da genética, é possível aperfeiçoar a espécie humana. Todavia, ao longo das discussões, observa-se a construção de uma percepção mais contextualizada da ciência e da tecnologia, permeada de influências ideológicas da sociedade e questionamentos acerca das consequências da manipulação genética e da divulgação de padrões humanos idealizados.
\end{abstract}

Palavras-chave: Formação de professores. Ensino de genética. Biologia molecular. Engenharia genética. Eugenia.

\begin{abstract}
New scientific and technological knowledge of molecular biology are increasingly present in society, becoming necessary in the scientific education of citizens. This article analyzes the teachers' speeches about genetic manipulation and human enhancement in the context of a continuing education course on the eugenics movement in the nineteenth and twentieth centuries. Data were collected by video recording,and were transcribed and analyzed by Discourse Analysis methodology. The results point to a gradual change in the positions of the teachers. Initially, the subjects have a more deterministic view when they mention that, through genetics, it is possible to refine the human species. However, during the discussions, the construction of a more contextualized perception of science and technology is observed, permeated with ideological influences from society and questions about the consequences of genetic manipulation and the dissemination of idealized human standards.
\end{abstract}

Keywords: Teacher training. Genetics education. Molecular biology. Genetic engineering. Eugenia.

\footnotetext{
${ }^{1}$ Universidade Tecnológica Federal do Paraná (UTFPR), Santa Helena, PR, Brasil.

E-mail: <eduardamaria.schneider@gmail.com>.

${ }^{2}$ Universidade Estadual de Londrina, Programa de Pós-graduação em Ensino de Ciências e Educação

Matemática, Londrina, PR, Brasil.

${ }^{3}$ Universidade Estadual de Maringá (UEM), Programa de Pós-graduação em Educação para a Ciência e a

Matemática, Maringá, PR, Brasil.
} 


\section{Introdução}

Se o século 20 serviu para a Biologia se consolidar como ciência (MAYR, 2005), o período atual se caracteriza pela intensa transformação nos estudos da vida. Uma das áreas que se modificou intensamente nos últimos anos foi a complexa biologia molecular. $\mathrm{Na}$ segunda metade do século 20, essa área dedicou especial atenção à estrutura e função dos ácidos nucleicos e seus produtos de expressão - as proteínas - e ao modo como os genes se expressam e são regulados. As modificações dos conhecimentos biológicos foram acompanhadas por criações de novas tecnologias, desencadeando a confluência dos termos biotecnologia e engenharia genética ou bioengenharia, que utiliza biotecnologias específicas para a manipulação de genes e recombinação gênica. Esses termos passaram, então, a ser pronunciados por muitos como sinônimos (OLIVEIRA, 2004; TIZIOTO; ARAUJO, 2008).

Os conhecimentos genéticos no século 20 foram permeados por uma crença de que o conhecimento sobre o DNA e sua manipulação permitiriam compreender e transformar os seres vivos. Contudo, o início do século 21 tem suscitado questionamentos acerca do reducionismo genético que se instaurou, promovendo uma percepção de um sistema molecular muito mais complexo e dinâmico (KELLER, 2000).

Algumas aplicações das transformações da biologia molecular foram: células-tronco e a perspectiva de regeneração tecidual e clonagem de órgãos; diagnóstico de doenças hereditárias; transgenia, aplicada principalmente na produção de alimentos e controle de pragas; sequenciamento de genes e genomas; aconselhamento genético; teste de paternidade; identificação molecular de pessoas; fertilização in vitro; terapia gênica. Esses novos procedimentos científicos e tecnológicos vêm sendo amplamente discutidos em todos os setores da sociedade e estão presentes nos mais diversos meios de comunicação (FÁVARO et al., 2003). Diante de tantas novas informações, torna-se urgente uma educação científica que proporcione o desenvolvimento da capacidade crítica, de modo que o sujeito tenha condições de avaliar os impactos das transformações científicas e biotecnológicas para a vida, sociedade e ambiente (BONZANINI; BASTOS, 2005), bem como os papéis dos discursos e ideologias que permeiam a ciência e tecnologia. Nessa perspectiva, as diversas instituições escolares têm o compromisso de integrar esses conteúdos a uma abordagem que permita o desenvolvimento da argumentação, reflexão e ação referentes às questões éticas, políticas e sociais envolvidas nessas temáticas, imprimindo ainda mudanças de hábitos e na mentalidade da sociedade (FÁVARO et al., 2003; FERREIRA; JUSTI, 2004). Dentre as questões que se colocam para reflexão, ressalta-se o exacerbado determinismo genético imbuído nos discursos atuais sobre os avanços biotecnológicos, muitas vezes com conotações que nos remetem aos movimentos eugênicos de um passado não muito distante.

Como afirma Vilas-Boas (2006), as grandes transformações científicas que ocorreram recentemente nas diversas áreas das ciências biológicas, especialmente na genética, geraram um volume muito grande de novas informações e de conhecimentos, nem sempre disseminado ou abordado de maneira adequada nos meios de divulgação científica e nos livros didáticos destinados ao Ensino Médio. Dentre os fatores que prejudicam a transposição didática dos conhecimentos científicos e biotecnológicos produzidos nas academias e centros de pesquisa, Banet e Ayuso (1995) adicionam a complexidade dos fenômenos e da construção conceitual na área da genética. Essa dificuldade se deve tanto à complexidade dos conceitos que essa área comporta quanto à forma de a escola conceber, organizar e desenvolver o ensino (BANET; AYUSO, 1995). 
O processo de ensino e aprendizagem de conceitos moleculares e genéticos é um desafio também para os professores envolvidos com a educação em ciências (JUSTINA; FERRARI, 2010).

Nesse sentido, observa-se a barreira alocada pela forma como esses conteúdos são abordados no ensino, costumeiramente com longas explicações teóricas e fragmentadas, de modo que os conceitos são vistos isoladamente, sem estabelecer as devidas correlações entre eles (GOLDBACH; EL-HANI, 2008; PEDRANCINI et al., 2007; SELLES; FERREIRA, 2005). Os conceitos biológicos trabalhados são, ainda, desprovidos do contexto histórico em que foram formulados, não permitindo compreender a ciência como um processo, muitas vezes, influenciado por condicionantes sociais, políticos e ideológicos. Desse modo, o ensino divulga a imagem ingênua da ciência como verdade e empreendimento neutro. No entanto, é importante destacar que um dos objetivos do Ensino de Ciências é justamente mostrar que os conceitos são dependentes do contexto histórico no qual se inserem, estando sujeitos a constantes reformulações (GIL-PEREZ et al., 2001).

É visível que o ensino de genética apresenta dificuldades por tratar de temas controversos e pela própria transformação que essa área tem passado, inclusive com o questionamento de dogmas centrais da própria genética, como a conceituação de gene face à percepção da complexidade das interações moleculares. Entretanto, a abordagem dessas temáticas no ensino de Biologia é imprescindível, tornando-se urgente a necessidade de uma formação de professores que permita compreender as novas discussões da Biologia. Nesse contexto, o objetivo deste artigo é analisar o discurso de professores das áreas das ciências naturais, que atuam na educação básica, acerca da relação entre o desenvolvimento da engenharia genética e o melhoramento genético humano, a partir de um debate sobre o tema, realizado durante um curso de formação continuada sobre a abordagem histórica da ciência, com destaque ao movimento eugênico ocorrido no final do século 19 e início do 20.

\section{A íntima relação entre a eugenia e os ideais do avanço da engenharia genética}

A história da genética é permeada por ideologias, que têm suas raízes em um período anterior à consolidação dessa área da ciência. Como destaca Oliveira (2004), a busca de uma base biológica para as características físicas entre as pessoas antecede a própria genética e se justifica pela necessidade de as classes dominantes e opressoras encontrarem um fundamento científico para seus argumentos racistas. Assim, Garcia (2008) argumenta que o discurso determinista da degenerescência da "raça" foi divulgado por grupos economicamente favorecidos para que pobreza, miséria e ignorância fossem encaradas de forma passiva pelos grupos economicamente desfavorecidos.

Nesse contexto, com o propósito de melhoramento da "raça", o movimento eugênico no século 19, preconizado por Francis Galton, pretendia o melhoramento biológico humano por meio do controle social da reprodução, buscando amparo em um discurso científico genético e evolutivo. Segundo pesquisadores da área (CASTAÑEDA, 2003; FARAH, 1997; OLIVEIRA, 2004), a eugenia foi entendida na época como uma ciência biológica experimental que estudava as influências que poderiam melhorar ou prejudicar física ou mentalmente as qualidades raciais 
da espécie humana, por meio de casamentos seletivos, estimulando a transmissão de características “desejáveis" e inibindo a transmissão daquelas “indesejáveis". O movimento eugênico teve seu auge com a Alemanha nazista de Adolf Hitler, mas esse foi também seu ponto de inflexão, marcando o momento de declínio do movimento e sua caracterização enquanto um programa racista, desvinculado de qualquer validade científica. Apesar disso, a eugenia não desapareceu totalmente do cenário científico, conforme afirma Del Cont (2007, p. 23):

[...] contudo, a eugenia não desapareceu como seria de se imaginar, ela se transformou; mas, ao se transformar conservou um núcleo teórico que se manteve inalterado e tem servido de orientação para novas roupagens eugênicas. Em outras palavras, manteve-se a ideia de que com a adequada informação genética poder-se-ia intervir no curso da reprodução humana, no sentido de se estabelecer, através de conhecimento científico, o seu devido controle e direcionamento. Parece-nos que temos, neste momento, movimentos em curso que lembrariam modelos ou programas eugênicos com a recolocação de antigas práticas articuladas em novos discursos. Por exemplo, contratos firmados entre empresas de biotecnologia e Estados com a finalidade de estudo e desenvolvimento de produtos baseados em informação genética da população, como o caso da empresa Decode Genetics com a Islândia e a empresa Autogen com Tonga e com a Tasmânia, que recolocam antigas tentativas de se construir um programa eugênico baseado na regulamentação estatal, agora também com interesses mercadológicos. Em uma outra perspectiva, poder-se-ia indicar uma nova forma de eugenia, que poderíamos classificar de razões eugênicas baseadas em decisões pessoais com relação à qualidade do material genético e o compromisso com as futuras gerações, gestores de novos referenciais para se pensar noções como identidade, pessoa e corporeidade.

Essa prática de discurso, com outra roupagem, mas com a mesma ideologia, constituise naquilo que Orlandi (2007b) considera o silêncio do discurso, que também está imbuído de significados. Desse modo, ocorre o silenciamento da palavra eugenia, mas com continuidade de uma ideologia dominante que busca justificar determinadas características humanas como ideal, com base em conhecimentos biológicos. Mai e Angerami (2006) apontam a consolidação dos ideais eugênicos em novos termos genéticos e nas respostas políticas e institucionais na sociedade contemporânea ao buscar meios de lidar com indivíduos portadores de "temores" genéticos. Isso pode ser exemplificado pela prática de aborto após diagnóstico pré-natal em nome do direito de ter uma criança sadia ou pela a seleção de embriões por meio de fertilização in vitro.

A busca por desvendar o DNA e identificar todos os genes humanos responsáveis, tanto pelas características normais como as patológicas, foi iniciada formalmente na década de 1990, quando surgiu o Projeto Genoma Humano (PGH) com o objetivo de mapear os genes nos cromossomos e determinar suas funções. Segundo Pereira (2001) e Gattás, Segre e Wünsch Filho (2002), o lançamento do PGH levou a concepção de um papel determinante do DNA em relação às características dos indivíduos, incluindo as de personalidade e comportamento. Essa visão professava que o DNA possuía informações codificadas (necessárias e suficientes) para 
determinar as características dos seres vivos, minimizando o papel do ambiente e da complexa rede molecular e celular. Em contrapartida, os dados obtidos pelo PGH e os conhecimentos genéticos em desenvolvimento na era pós-genômica, século 21, em vez de apoiar as noções familiares de determinismo genético, criaram desafios críticos a essas noções, ao evidenciar a complexidade das influências externas ao ativarem ou silenciarem certos genes (RAMOS, 2010). O PGH foi importante para evidenciar a complexidade da dinâmica celular, uma vez que se imaginava que o número de genes no genoma humano fosse muito superior ao encontrado. Como afirmam Fardilha, Silva e Silva (2008, p. 40),

[...] depois de vários genomas terem sido completamente descritos, como o de Caenorbabditis elegans, um nemátode com pouco mais de 1000 células e 19.500 genes, ou o do milho, com aproximadamente 40.000 genes, pensou-se que o genoma humano consistiria em mais de 100.000 genes. No entanto, o Projeto do Genoma Humano revelou, com alguma surpresa, que existiam pouco mais de 30.000 genes codificantes.

A explicação para esse fato foi que o genoma humano produzia uma grande variedade de proteínas mediante um número reduzido de "genes" por meio do processamento alternativo do RNA. Para Nascimento (2003), os dados obtidos no sequenciamento do genoma humano tiveram um papel fundamental para apontar a ingenuidade das esperanças suscitadas com a definição dos objetivos originais do projeto. O conhecimento das sequências de DNA não se revelou suficiente para o entendimento de como os organismos se desenvolvem, funcionam e evoluem (NASCIMENTO, 2003). Nesse contexto, o PGH acabou proporcionando uma visão mais sistêmica, em que as partes estão relacionadas, ou seja, que o DNA é apenas mais uma molécula a integrar a complexa rede de relações que constituem o organismo, evidenciando as inconsistências do conceito molecular clássico de gene. De acordo com Keller (2000), em vez de reforçar as noções familiares do determinismo genético - por meio das quais o gene se tornou a entidade conceitual central da apoteose da genética do século 20 -, os resultados do sequenciamento completo do genoma humano teriam, ao contrário de todas as expectativas, suscitado um desafio crítico a essas noções clássicas da história da genética.

No auge das promessas deterministas do PGH, Bizzo (1995) passou a alertar sobre a reedição das ideias eugênicas no contexto das perspectivas do Projeto Genoma e da clonagem de embriões humanos. Para ele, a clonagem e replicação de embriões humanos e o avanço das técnicas da engenharia genética para modificá-los demonstrariam a não superação das propostas da eugenia. Todavia, mesmo com a percepção da complexidade do sistema molecular, evidenciada principalmente após o PGH, as novas biotecnologias continuam permeando o imaginário das pessoas e vêm sendo utilizadas de forma cada vez mais crescente na seleção de embriões, principalmente em casos de doenças genéticas na família. Assim, existe uma busca pela saúde da própria descendência, ignorando a relação entre desejo pessoal e fatos de natureza coletiva e excludente. Em consequência, novos dilemas e desafios legais, éticos e morais dividem as opiniões, tais como: responsabilidade para realização do aconselhamento genético; diagnóstico pré-implantacional; abortamento terapêutico; programas de triagem neonatal e populacional; métodos de identificação humana; acesso e uso do genoma humano; criação de bancos de células e DNA; terapia gênica. Portanto, já não é possível visualizar uma fronteira tão bem delimitada 
entre a seleção das características genéticas desejadas e a prevenção e eliminação de embriões com fatores indesejados, ou seja, uma decisão de caráter eugênico (FARAH, 1997; ZATZ, 2011).

Muitos equívocos ainda hoje são provocados pela falsa ideia de classificar a eugenia como um tema referente apenas ao início do século 20 e na dificuldade de compreender a relação entre as práticas eugênicas da época e a utilização das Novas Tecnologias Reprodutivas Conceptivas (NTRc) do século 21. De acordo com Mai e Angerami (2006), a busca da implantação de embriões "perfeitamente sadios" nas tecnologias reprodutivas representa a clara expressão da preocupação do ser humano em relação à sua descendência, o que há algum tempo atrás seria expresso pelo discurso dos ideais eugênicos ao tentar "aperfeiçoar as qualidades e reduzir ao mínimo as imperfeições humanas” (MAI; ANGERAMI, 2006, p. 253). Portanto, existe uma mudança do discurso eugênico do passado para o presente, ao passo que no passado a "seleção" das características desejáveis buscava alcançar o "melhoramento da espécie humana" por meio dos cruzamentos entre as consideradas "raças superiores", atualmente os cientistas transitam no campo das moléculas genéticas.

Mai e Boarini (2002) chamam a atenção para o "deslocamento do referencial" da eugenia em forma de práticas macrossociais, de violência racial e esterilizações em massa, para formas ultramoleculares da genética. Como podemos exemplificar, no seguinte caso:

[...] no início do século XX, em pleno auge do movimento eugenista mundial e brasileiro, uma medida eugenista de caráter negativo era limitar que casais com doenças genéticas procriassem para evitar o nascimento de filhos portadores de tais doenças. Propunha-se, então, a esterilização, a segregação de doentes mentais, ou o aborto, medidas socialmente muito criticadas. Hoje, casais nas mesmas condições têm à sua disposição biotecnologias que vêm prometendo retirar o gene defeituoso, o que reflete uma mesma medida eugenista de caráter negativo. O que mudou? Mudou o caminho intervencionista para a obtenção do mesmo resultado e o ideário a que se veicula. Se comparado à crítica sobre os métodos anteriormente propostos, hoje é possível que seja condenado o casal que não faça uso dessa biotecnologia para alcançar o mesmo fim. Ambas são medidas eugenistas. Condena-se uma, pelo histórico abuso praticado sobre determinados grupos sociais em nome da boa procriação; aceita-se outra, por justificar um benefício à futura prole da família. Qual o limite entre as duas? (MAI; ANGERAMI, 2006, p. 253).

\footnotetext{
${ }^{4}$ A palavra melhoramento, que muitas vezes é utilizada em livros didáticos de Biologia, implica um julgamento de valor que é atribuído de acordo com uma dada sociedade, ou seja, configura-se em uma visão antropocêntrica sobre a diversidade dos seres vivos. Cabe ressaltar que o ser humano é apenas mais uma espécie - recente - na história da evolução biológica e, em termos biológicos, não existem seres vivos ou características "melhores" ou "piores", uma vez que o ambiente é mutável e os seres que sobrevivem estão aptos às contingências ambientais nas quais se inserem.
} 
O mapeamento completo do DNA, a terapia gênica, a manipulação genética, a clonagem humana, o screening genético (identificação de indivíduos afetados por doença genética), a PCR (Polymerase Chain Reaction ou Reação em Cadeia da Polimerase - replicação de DNA), a testagem preditiva para genes defeituosos, as vacinações genéticas, entre muitas outras técnicas, constituem um amplo conjunto que reflete a velocidade com que a engenharia genética vem desenvolvendo-se. De fato, os benefícios gerados por todas essas possibilidades são inúmeros, porém, cabe aos indivíduos compreender criticamente esses conhecimentos e assumir seu posicionamento, fazendo-se respeitar sua escolha, evitando um novo padrão ideológico discriminatório e de violência racial como as práticas eugênicas do século 20 (MAI; BOARINI, 2002). Assim, tendo em vista os desenvolvimentos da genética, torna-se de extrema importância compreender e adquirir uma postura crítica a respeito do conhecimento científico vinculado a velhos discursos ideológicos discriminatórios e racistas. É, por isso, importante indagar até que ponto a engenharia genética contribui para a saúde e bem-estar da população e até que ponto elas podem constituir mais uma forma de discriminação (BRAZ, 2007; DEL CONT, 2007). Porém, para compreender e se posicionar diante dessas informações, é necessária uma base de conhecimento sobre ciência e tecnologia que deve ser oferecida pela escola, sendo esta a principal responsável em promover a imprescindível alfabetização científica.

\section{Metodologia}

A presente pesquisa foi realizada com 16 professores da educação básica, das áreas de Biologia, Física e Química, durante a promoção de um curso sobre História e Epistemologia da Ciência, solicitado pelo Núcleo Regional de Educação (NRE) de Toledo-PR aos professores da área de Ensino de Ciências da Universidade Estadual do Oeste do Paraná (Unioeste). Informações e esclarecimentos sobre os objetivos e procedimentos de coleta de dados para a investigação foram feitos antes de iniciar o curso, realizado em 2012, e todos os professores aceitaram de forma positiva participar como sujeitos da pesquisa. O curso de formação continuada para professores ocorreu em dois dias, contabilizando 16 horas de atividades presenciais, que objetivaram estudar as influências ideológicas e biológicas que permearam o movimento eugênico e os limites e possibilidades para trabalhar essa temática no Ensino de Ciências. Esperava-se que as discussões fornecessem subsídios para um ensino do conhecimento biológico contextualizado em sua conjuntura histórica e social, desmistificando a ideia da ciência como neutra e linear.

No primeiro dia, após as assinaturas dos termos de consentimento para a participação na pesquisa, o curso teve início com a aplicação de um questionário inicial para a coleta de dados sobre os conhecimentos prévios dos professores acerca das implicações dos desenvolvimentos biotecnológicos atuais. A aplicação do questionário foi seguida pela promoção de um debate sobre técnicas de manipulação genética, melhoramento genético e predisposição a doenças genéticas. O debate subsidiou a leitura e discussão da reportagem: "Como fazer Super Bebês" (COSTA; GARATTONI, 2012), que apresentou várias pesquisas atuais que estão sendo realizadas na área da genética molecular, idealizando um ser humano livre de doenças genéticas e com melhor desempenho físico e intelectual. Após a discussão, foram distribuídos aos professores 20 artigos originais (fontes primárias) publicados no Boletim de Eugenia dos anos de 1929, 1930 
e 1931, para eles lerem, apresentarem e contraporem com a reportagem anterior. Os artigos tratavam dos propósitos da eugenia no Brasil, tais como: aperfeiçoamento e controle da natalidade, fundamentos científicos da eugenia, educação eugênica, educação sexual, esterilização em prol da eugenia e eugenia como ciência e ideal social.

No segundo dia de formação continuada, foram retomadas as discussões realizadas na primeira etapa, relacionando a reportagem sobre as atuais pesquisas genéticas com os artigos dos Boletins de Eugenia. Em seguida, foram distribuídos vários trechos originais, sem identificação, de alguns autores que subsidiaram o trabalho da eugenia de Galton, especificamente Darwin, Lamarck e Mendel, solicitando-se aos professores para nomearem o autor do trecho de acordo com suas concepções, discutirem e compararem os originais ao exposto nos livros didáticos. Como atividade para trabalhar o conteúdo teórico da eugenia foi feita uma apresentação de slides. Outra atividade foi a leitura e discussão do texto "Impacto da Biotecnologia na Biodiversidade" (BORÉM, 2005). Logo depois, foram apresentados dois filmes como possibilidades para os professores trabalharem em sala de aula - GATTACA: experiência genética e Homo Sapiens 1900. Para finalizar, fez-se um debate sobre os filmes e como os professores trabalhariam esse movimento na sala de aula em conjunto com as biotecnologias atuais. Posteriormente, eles responderam ao questionário final para a coleta de dados da pesquisa.

No presente artigo, apresenta-se a análise do debate inicial praticado com os professores, referente às técnicas de manipulação genética, melhoramento genético e predisposição a doenças genéticas a partir da leitura e discussão de uma reportagem de divulgação científica. As falas dos professores durante as discussões, registradas por videogravação, foram organizadas em fragmentos (identificados por fragmento 1, fragmento 2, fragmento 3...) e analisadas de acordo com a metodologia da Análise de Discurso, segundo Orlandi (2007a). Nos fragmentos de discursos apresentados, os professores foram identificados pela letra P, seguida de numeração, e, as professoras mediadoras da discussão pela letra $\mathrm{M}$, seguida de numeração.

Tendo em vista que os dados da presente pesquisa são decorrentes de um movimento histórico, cercado de perspectivas ideológicas sociais, que de certa forma ainda tem impactos na atualidade, optou-se por utilizar a metodologia da Análise de Discurso (AD), que Orlandi (1996, p. 30) define como "método clássico de análise de linguagem que trata dos conteúdos da linguagem, dos conteúdos da ideologia". A AD busca analisar o funcionamento do discurso na produção de sentidos, podendo-se, assim, explicitar o mecanismo ideológico que o sustenta, ou seja, a explicitação do modo como o discurso produz sentidos (ORLANDI, 2007a). O discurso acontece na história por meio da linguagem oral ou escrita e se configura em uma das instâncias na qual a ideologia se materializa. Assim, para a análise de discurso, a linguagem deve ser estudada não só em relação ao seu aspecto gramatical, exigindo de seus usuários um saber linguístico, mas também em relação aos aspectos ideológicos e sociais que se manifestam por meio de um saber socioideológico (ORLANDI, 2007a). Para a AD, o discurso é uma prática, uma ação do sujeito sobre o mundo. Por isso, sua aparição deve ser contextualizada como um acontecimento, uma vez que dá origem a uma interpretação e constrói uma vontade da verdade. Os discursos se movem em direção a outros. Nunca está só, sempre está atravessado por vozes que o antecederam e mantêm com ele constante duelo.

$\mathrm{Na}$ pesquisa aqui apresentada, o corpus para a análise se constituiu na seleção de fragmentos nas falas dos professores durante a discussão, no qual se buscou verificar as condições de produção do discurso emitido. 


\section{Resultados e Discussões}

\section{Concepções de professores em exercício sobre manipulação genética e melhoramento humano}

No primeiro dia do curso de formação continuada, após os professores responderem ao questionário inicial, iniciou-se uma discussão sobre algumas questões relacionadas à História da Ciência e ao movimento eugênico. Uma dessas questões buscava verificar as percepções dos professores sobre o determinismo genético, como se observa no Fragmento 1:

\section{FRAGMENTO 1}

M2: Vocês acreditam que tem como aperfeiçoar a população humana? O que vocês acreditam? Teria como aperfeiçoar a população humana?

M1: Porque foi uma discussão que teve no movimento eugênico, do aperfeiçoamento da raça humana, é possível esse aperfeiçoamento, em que sentido? P8: Pela genética. Geneticamente.

M2: Só geneticamente?

P8: Não adianta só mudar os aspectos físicos, tem que mudar o restante também, na genética a gente muda o físico.

P15: Na genética, a gente muda esteticamente, mas agora na escola, nós, educadores, tentamos mudar o eu pessoal, mas também não estamos conseguindo, nós estamos batalhando, mas cada vezparece que o barco afunda mais, a impressão que dá é que nós estamos perdendo a força.

M2: Pensando no que a colega falou, na questão de aperfeiçoar a população humana ela citou então, pela genética e pela educação, alguém tem mais alguma colocação?

P16: Eu acho que tem muito adolescente no Ensino Médio que rouba, adolescente frustrado, revoltado, não adianta mudar a genética, tem que mudar as condições [...].

P3: Quem trabalha genética vivencia uma interação entre fenótipo e genótipo, então, na realidade, o que nós estamos falando aqui é genótipo e fenótipo. Geneticamente, nós podemos aperfeiçoar uma pessoa. Talvez, no futuro, consigamos. Agora a questão do meio ambiente, a questão das condições ambientais que integram o fenótipo, se nós não mudarmos o fenótipo nós, não aperfeiçoamos nada, supomos que você não tem o controle sobre o vírus da rubéola, mas você tem um genética perfeita entre o espermatozoide e o óvulo que se fecundaram e você colocou no útero de uma mulher, mas você não tem o controle sobre esse vírus é uma interação do genótipo, quer dizer, você não vai formar uma pessoa mais inteligente, mais forte, você pode ter um problema sério de deficiência, então sempre lembrando que é a interação [...].

M2: Então você acha que o genótipo teria como aperfeiçoar geneticamente e o fenótipo é educação, política pública? 
P3: Eu sempre uso o seguinte exemplo: tem dois gêmeos univitelinos, o genótipo é o mesmo, eu pego um desses gêmeos e entrego para ela o outro levo para uma favela lá no Rio de Janeiro. Daqui a vinte anos eles vão ser iguais? Então genótipo e fenótipo nós não podemos garantir sem as condições sociais, sem as condições ambientais perfeitas, nós não podemos garantir uma raça melhor, como a eugenia propunha uma raça melhor.

Ao serem questionados sobre a possibilidade do melhoramento/aperfeiçoamento humano, inicialmente, os professores recorrem a uma explicação genética, como explicita a primeira fala de P8. Esse discurso é carregado de sentidos oriundos de parte da vida desses sujeitos, enquanto professores das ciências naturais, alguns dos quais da área de biologia, instantaneamente, ao ouvir o termo "melhoramento", remetem à genética. No entanto, ao longo da discussão, ao serem questionados pelas mediadoras, os professores passam de uma visão mais determinista para uma mais contextualizada, que considera as condições sociais e políticas em suas explicações. Percebe-se que o discurso dos professores se volta para o lugar que eles ocupam na sociedade, de educadores e formadores, onde presenciam a realidade social de seus alunos e observam as diferenças de classes que influenciam as condições ambientais dos diferentes indivíduos da sociedade. Contudo, nessa discussão inicial, ainda não questionam os juízos de valores daquilo que é considerado ideal em uma sociedade, nem rompem com uma visão reducionista genética e ambiental, uma vez que desconsideram o papel do organismo na modificação das condições ambientais.

Ao longo da discussão, todavia, os professores chegam à conclusão de que aquilo que é considerado melhor ou pior é dependente de um contexto. Nota-se que a reflexão coletiva de professores permite a construção de um conjunto de ideias e de um discurso mais elaborado e contextualizado, corroborando com Göttems (2003) ao afirmar que a reflexão propicia a construção do conhecimento. Os professores ainda questionam quais seriam as consequências no futuro de uma seleção de características, como se pode observar no fragmento 2 :

\section{FRAGMENTO 2}

M1: [...] Se eu modificar geneticamente, eu consigo coisas melhores? Será que existe isso? Será que existe melhor ou pior para o ser humano? P13: Como nos vegetais, as sementes eles já deixam só as melhores. M2: Só em vegetais? Será que não chegou ao humano ainda?

P2: Depende para o que é essa melhoria. Por exemplo, nos vegetais está mudando geneticamente para uma producão melhor, com objetivo, selecionando algumas características dele que tenham vantagem economicamente, resistência.

P9: Resistência a pragas, maior produção, agora, qual é o objetivo disso? É melhorar em que sentido? É melhor para quem? É melhor no quê?

P2: O que é melhor para um pode não ser melhor para o outro.

P1: E quais seriam os benefícios e os malefícios para nós?

M1: Aí que a gente estava querendo associar, apesar de o movimento eugênico ter ficado lá atrás, ele de alguma forma se relaciona com o que vocês estão falando, dessas questões de seleção. E se a gente transferisse isso 
para o humano? Será que é possível selecionar e melhorar o ser humano geneticamente?

P9: Pensando assim, comparando com as outras, pela condição genética, pela evolução que nós temos, por exemplo, é possivel você selecionar o sexo, é possivivel você selecionar a questão de resistência a doenças. Agora é como a P1 disse antes, o que isso no futuro vai trazer em contrapartida? Então você vai melhorar e tornar resistente a uma doença, mas será que isso não vai tražer em contrapartida outros problemas que podem desenvolver outras doenças?

Observa-se que as frases dos professores são carregadas de condicionantes ideológicos postos na sociedade sobre os ideais de discriminar melhores características. A comparação do melhoramento humano com o melhoramento vegetal leva a reflexões do tipo: qual o objetivo? Melhorar o que e para quem? Essa reflexão indica que os professores conseguem elaborar um discurso mais crítico com relação às ideologias que a sociedade incute nos indivíduos a ponto de classificar um como melhor que outro. Para ampliar as discussões, elencamos outra questão, exposta no fragmento 3:

\section{FRAGMENTO 3}

M2: Mas então vou te fazer outra pergunta, você é a favor ou não da manipulação genética em relação aos seres humanos?

P12: Eu acho o seguinte: pego o exemplo da transgenia. Se fosse fantástico, todos os alimentos que nós temos hoje, todos eles seriam clonados geneticamente [...]. Eu acho que por ai tem outras questões de ser a favor ou não. Por exemplo, eu sou a favor, sim, de quem tem uma doença curá-lo e ai a genética evoluiu tanto que eu posso pegar um pulmão de um porco e colocar no ser humano; você dá uma sobrevivência.

M2: Então na questão de doenças, você é a favor?

P12: Eu acho que é melhoria, mas daí a qualidade é isso que a gente está questionando hoje. Até que ponto, que preço?

P15: A sobrevida esta aí, mas o preço que paga, vale a pena?

P16: Eu vejo assim: tem um monte de coisas a favor, várias vantagens, no caso. Só que a evolução daí, da espécie humana, ela já não vai se dar no processo natural. O que nós evoluimos ao longo dos anos, desde a origem do ser humano ela foi um processo natural; a partir do momento que a gente manipula, aí que vem as consequências disso, não tem como prever, a gente pode manipular, mas e a consequência disso?

É possível identificar que os professores reproduzem a preocupação da nossa época sobre as discussões do campo da ética e da religião quanto às consequências da tecnologia genética. Alguns professores mencionaram que são a favor da manipulação genética em casos de doenças, mas, ao mesmo tempo, outros rebatem, questionando as consequências dessa biotecnologia.

A discussão também possibilitou refletir sobre uma visão mais sistêmica dos processos biológicos, evidenciando que há toda uma interação celular com sinalizadores e promotores que auxiliam nos processos metabólicos. Segundo Keller (2005), é de extrema importância abordar 
no ensino a intrincada rede de interações celulares e orgânicas que envolvem a molécula de DNA e seus processos, como replicação, transcrição e tradução em proteínas e RNAs. Seguiuse a discussão com o objetivo de promover uma visão mais ampla do conhecimento científico e da complexidade biológica:

\section{FRAGMENTO 4}

M1: E o que a gente percebe dessa discussão? A complexidade biológica é tão grande, são muitos fatores que interferem, não só no nosso organismo, se a gente pensar no nosso organismo, nossas células também, a gente tem o mesmo DNA nas células, tudo bem, mas por que nossas células se diferenciam tanto se é o mesmo DNA? Porque eu tenho elementos na divisão celular, eu vou dividindo de maneira diferente a célula, os elementos fora da célula, a polarização dessa célula, então eu tenho elementos diferentes nos tecidos que vão dar instruções para esse DNA, então é uma complexidade muito grande, e, na natureza, fora do corpo, nas populações também a complexidade biológica é tão grande que a interferência em um certo fator a gente não sabe direito o que a gente pode até interferir, até fazer estudos tentar interferir de forma adequada, mas a gente nunca sabe totalmente os caminhos que vai tomar, porque é uma complexidade muito grande. $\mathrm{O}$ elemento que eu introduzo ali é diferente, a espécie é diferente, que seja dentro de uma população, acaba interferindo nessas populações, eu prevejo parcialmente, eu sei um pouco o comportamento dessa espécie, eu posso prever parcialmente, mas é tão complexo, é tão imbricado de relações que esses caminhos podem fugir do controle.

P1: Por isso que o avanço tecnológico, as pesquisas são de suma importância, mas o risco às vezes ocorre de até aonde chegar, o que pode vir a acontecer? $O$ avanço é uma necessidade nossa, agora as implicações disso no nosso dia a dia que é complicado, e aí a gente tem que pensar na questão da ética, no que qualquer ação minha vai implicar e isso a pesquisa, como você falou, ela visualiza a até certo ponto. E dai para frente? Agora, depois que a pesquisa já aconteceu? Depois que, digamos, o mal está feito, como você vai conseguir reverter isso?

P16: Mas assim, o que eu penso: se for lá para um hospital e você pegar lá todas aquelas pessoas doentes em tratamento, quimioterapia, rádio, você vai lá e pergunta para um deles: “o que você acha se a gente fosse lá e manipulasse geneticamente e descobrisse uma maneira de nunca mais alguém ter câncer?" Todo mundo vai querer. Quem que vai querer ter câncer? Eu acompanbei minha avó com câncer nos últimos tempos, é uma rotina desgastante a luta contra o câncer. Sabe, existe o tratamento? Existe, minha avó é idosa e está lá viva se tratando, está bem, só que pelo amor de Deus [...]. M1: Vocês gostariam de saber antes a herança, se tem uma tendência, uma predisposição? [...]

P13: Pode até a pessoa descobrir antes, mas todos que descobrem vão ter condições financeiras para pagar esse tratamento que vai precisar? Eu acho que esse é o pior problema. 
P6: É sempre assim, sempre vai cair na questão financeira, é o que move, o que manda.

P15: Mas se descobre antes, ela não vai ter se manifestado ainda, vai evitar que ela venha a ocorrer né.

P2: Eu acho que é justamente a questão da prevenção, por exemplo, se essa medida de conhecer se vai ter a doença, se tem como você prevenir, as medidas que você toma até lá, se ajudam na prevenção dessa doença, eu acho que é válido, mas aí tem toda a situação financeira, tem a situação do tipo de doença, enfim, se pode ter uma prevenção que teu modo de vida pode vir a influenciar decisivamente com relação a ter ou não aquela doença. Então isso é muito relativo depende sempre, tem os dois lados da moeda, você tem o lado que ajuda e o lado que atrapalha. Agora se você colocar na cabeça eu vou ter tal coisa e vai ficar se martirizando por isso, você vai ter outros problemas.

M1: E pode gerar discriminação?

P15: Com certeza.

M2: Por exemplo, saiu há um tempo uma reportagem que falava que, em um futuro próximo, as pessoas vão ser selecionadas nos seus empregos, na vida social, por meio do seu genoma, por suas características genéticas, por suas doenças e tal. Será que já não tem um pouquinho disso hoje em dia? P13: Já, pelo que nós vimos no jornal ontem já têm, quem passou no concurso está sendo discriminado porque tem miopia ou por ter outra doença.

M2: E isso é o quê?

M1: É uma forma de seleção humana.

P16: É verdade, tipo se você passou na prova, em um concurso, se você tem algumas varizes na perna você não conta, porque se você tem você não entra. Então é assim, é discriminado por tudo.

M1: Então de certa forma não é uma eugenia? Selecionar os melhores, os mais sadios?

No fragmento, evidencia-se o consenso entre os professores da importância dos avanços científicos e tecnológicos. No entanto, em diversos momentos da discussão, os professores questionam o acesso às tecnologias inovadoras e para onde caminha a ciência. Além disso, durante as discussões, percebe-se que os professores têm noção dos aspectos sociais e econômicos que interferem na aplicação e utilização do conhecimento científico, como evidenciado nas falas de P13 e P6. Outro ponto destacado nesse fragmento é a questão das discriminações geradas na sociedade devido aos padrões idealizados. Nesse momento, a mediadora M1 aproveita para relacionar esses aspectos com a eugenia, questionando aos professores se as tecnologias genéticas não seriam, de certa forma, um tipo de eugenia.

Evidencia-se por meio das discussões dos fragmentos 1, 2, 3 e 4 que o curso proporcionou aos participantes um espaço para reflexões e discussões críticas sobre o tema, manipulação genética humana, contextualizado histórico e socialmente com questões atuais que fazem parte do dia a dia dos participantes. Essa constatação destaca a importância de espaços coletivos de formação que buscam promover o professor como profissional crítico-reflexivo com vista à melhoria da prática pedagógica, pois o conhecimento construído por ele nos momentos de reflexão crítica entre teoria e prática permite a melhoria da prática docente (GARCÍA, 1992; GÖTTEMS, 2003; PIMENTA; GHEDIN, 2002; SCHÖN, 2000). 


\section{Considerações finais}

Vários autores concordam que, devido às extraordinárias mudanças da genética, é indispensável que o público em geral tenha mais e melhores informações sobre essa ciência, para compreender suas aplicações e implicações, formando cidadãos críticos para discutir os rumos e os usos dos avanços científicos e suas implicações sociais, éticas, políticas e econômicas (JUSTINA; FERRARI, 2010; SCHEID; FERRARI; DELIZOICOV, 2005; XAVIER, FREIRE; MORAES, 2005). Nesse contexto, este artigo buscou apresentar a proposta de um curso de formação continuada sobre eugenia na abordagem histórica da ciência e avaliar uma discussão referente à manipulação genética humana com professores da educação básica.

A análise dos dados apontou que, inicialmente, os professores apresentaram uma visão mais determinista sobre o questionamento do melhoramento humano, afirmando que poderíamos alcançar esse ideal pela genética. Entretanto, no decorrer do debate, observou-se a construção de uma percepção mais contextualizada e crítica sobre o assunto, pois, mediados pelas discussões empreendidas, os professores passam a questionar o avanço das técnicas genéticas, bem como as influências ideológicas e sociais vinculadas à construção científica. Além disso, os professores refletiram, ainda, sobre quem classifica e, sob quais parâmetros, determinadas características como melhores que outras, relacionando a questão das discriminações geradas na sociedade à construção de padrões humanos idealizados.

Ao verificar os resultados das discussões, pondera-se a importância de levar temas de ampla relevância social e divulgação para cursos de formação continuada que possam garantir a reflexão dos professores, visto que estes são os responsáveis por formar cidadãos conscientes, críticos e éticos para atuar em sociedade.

\section{Agradecimento}

À Coordenadoria de Aperfeiçoamento de Pessoal de Nível Superior (Capes), pela concessão de bolsa do Programa Nacional de Pós Doutorado (PNPD) à segunda e terceira autora deste trabalho.

\section{Referências}

BANET, E.; AYUSO, E. Introducción a la genética en la enseñanza secundaria y bachillerato: contenidos de enseñanza y conocimientos de los alumnos. Enseñanza de las Ciencias, Barcelona, v. 13, n. 2, p. 137-153, 1995. Disponível em: < http://raco.cat/index.php/ Ensenanza/article/view/21403/93363>. Acesso em: 4 jul. 2016.

BIZZO, N. M. V. Eugenia: quando a biologia faz falta ao cidadão. Cadernos de Pesquisa, São Paulo, n. 92, p. 38-52, fev. 1995. Disponível em: <http://www.fcc.org.br/pesquisa/ publicacoes/cp/arquivos/694.pdf>. Acesso em: 4 jul. 2016. 
Discursos de professores em formação continuada ...

BONZANINI, T. K.; BASTOS, F. Concepções de alunos do ensino médio sobre clonagem, organismos transgênicos e Projeto Genoma Humano. In: ENCONTRO NACIONAL DE PESQUISA EM EDUCAÇÃO EM CIÊNCIAS, 5., 2005, Bauru. Atas... Bauru: Associação Brasileira de Pesquisa em Ensino de Ciências, 2005. p. 1-13. Disponível em: < http://www. nutes.ufrj.br/abrapec/venpec/conteudo/artigos/1/pdf/p628.pdf>. Acesso em: 4 jul. 2016.

BORÉM, A. Impacto da biotecnologia na biodiversidade. Biotecnologia, Ciência

\& Desenvolvimento, Brasília, n. 34, p. 22-28, 2005. Disponível em: < http:/ /www. biotecnologia.com.br/revista/bio34/bio34.pdf>. Acesso em: 4 jul. 2016.

BRAZ, M. Conhecimento das informações genéticas: benefícios e riscos individuais. In: EMERICK, M. C.; MONTENEGRO, K. B. M.; DEGRAVE, W. (Org.). Novas tecnologias na genética humana: avanços e impactos para a saúde. Rio de Janeiro: [GESTEC], 2007. p. 183-188.

CASTAÑEDA, L. A. Eugenia e casamento. História, Ciências e Saúde, Manguinhos, Rio de Janeiro, v. 10, n. 3, p. 901-930, set/dez., 2003.

COSTA, C.; GARATTOONI, B. Como fazer super bebês. Super Interessante, São Paulo, n. 301, fev. 2012. Disponível em: < http://super.abril.com.br/ciencia/ como-fazer-super-bebes>. Acesso em: 4 jul. 2016.

DEL CONT, V. D. A ciência do melhoramento das especificidades genéticas humanas. Campinas: [s. n.], 2007.

FARAH, S. B. DNA: segredos \& mistérios. São Paulo: Sarvier, 1997.

FARDILHA, M.; SILVA, O. C.; SILVA, E. C. A importância do mecanismo de "splicing" alternativo para a identificação de novos alvos terapêuticos. Acta Urológica, Lisboa, v. 25, n. 1, p. 39-47, 2008. Disponível em: <http://www.apurologia.pt/acta/1-2008/splicing.pdf>. Acesso em: 4 jul. 2016.

FÁVARO, R. D. et al. Engenharia genética e biologia molecular: possibilidades e limites do trabalho do professor de biologia no ensino médio. In: ENCONTRO NACIONAL DE PESQUISA EM EDUCAÇÃO EM CIÊNCIAS, 4., 2003, Bauru. Atas... Bauru: ABRAPEC, 2003. p. 1-11.

FERREIRA, P. F. M.; JUSTI, R. S. A abordagem do DNA nos livros de biologia e química do ensino médio: uma análise crítica. Ensaio: pesquisa em educação em ciências, Belo Horizonte, v. 6, n. 1, p. 1415-2150, 2004. Disponível em: <http://www.portal.fae.ufmg.br/ seer/index.php/ensaio/article/viewFile/79/122>. Acesso em: 4 jul. 2016.

GARCÍA, C. M. A formação de professores: novas perspectivas baseadas na investigação sobre o pensamento do professor. In: NÓVOA, A. (Org.). Os professores e a sua formação. Lisboa: Dom Quixote, 1992. p. 51-76.

GARCIA, J. L. A automobilização da ciência para a criação de aparelhos de identificação e de coacção estatal em finais do século XIX. In: FROIS, C. (Org.). A sociedade vigilante: ensaios sobre identificação, vigilância e privacidade. Lisboa: Imprensa de Ciências Sociais, 2008. p. 43-65. 
GATTÁS, G. J. F.; SEGRE, M.; WÜNSCH FILHO, V. Genética, biologia molecular e ética: as relações trabalho e saúde. Ciência \& Saúde Coletiva, São Paulo, v. 7, n. 1, p. 159-167, 2002. Disponível em: <http://dx.doi.org/10.1590/S1413-81232002000100014>. Acesso em: 4 jul. 2016.

GIL-PEREZ, D. et al. Para uma imagem não deformada do trabalho científico. Ciência \& Educação, Bauru, v. 7, n. 2, p. 125-153, 2001. Disponível em: < http://dx.doi.org/10.1590/ S1516-73132001000200001>. Acesso em: 4 jul. 2016.

GOLDBACH, T.; EL-HANI, C. N. Entre receitas, programas e códigos: metáforas e ideias sobre genes na divulgação científica e no contexto escolar. Alexandria: revista de educação em ciência e tecnologia, Florianópolis, v. 1, n. 1, p. 153-189, 2008. Disponível em: <https:// periodicos.ufsc.br/index.php/alexandria/article/view/37428/28750>. Acesso em: 14 jun. 2010.

GÖT'TEMS, K. F. R. Formação continuada dos professores das séries iniciais do ensino fundamental na Rede Municipal de Ensino de Curitiba. 2003. Dissertação (Mestrado em Educação) - Pontifícia Universidade Católica do Paraná, Curitiba, 2003.

JUSTINA, L. A. D.; FERRARI, N. A ciência da hereditariedade: enfoque histórico, epistemológico e pedagógico. Cascavel: Ed. Edunioeste, 2010.

KELLER, E. F. The century beyond the gene. Journal of Biosciences, Bangalore, v. 30, n. 1, p. 3-10, Feb. 2005.

The century of the gene. Cambridge, MA: Harvard University Press, 2000.

MAI, L. D.; ANGERAMI, E. L. S. Eugenia negativa e positiva: significados e contradições.

Revista Latino-Americana Enfermagem, Ribeirão Preto, v. 14, n. 2, p. 251-258, 2006.

Disponível em: <http://dx.doi.org/10.1590/S0104-11692006000200015>. Acesso em: 4 jul. 2016.

MAI, L. D.; BOARINI, M. L. Estudo sobre forças educativas eugênicas no Brasil, nas primeiras décadas do século XX. Ciência, Cuidado e Saúde, Maringá, v. 1, n. 1, p. 129-132, 2002. Disponível em: <http://ojs.uem.br/ojs/index.php/CiencCuidSaude/ article/viewFile/5682/3606>. Acesso em: 4 jul. 2016.

MAYR, E. Biologia, ciência única: reflexões sobre a autonomia de uma disciplina científica. São Paulo: Companhia das Letras, 2005.

NASCIMENTO, M. L. O desencantamento do dom científico: a prevalência da metáfora do programa genético no Projeto Genoma Humano e o contexto históricosocial da industrialização das biociências. 2003. 100 f. Dissertação (Mestrado) - Instituto de Medicina Social, Universidade do Estado do Rio de Janeiro, Rio de Janeiro, 2003.

OLIVEIRA, F. Engenharia genética: o sétimo dia da criação. 2. ed. reform. São Paulo: Moderna, 2004.

ORLANDI, E. P. A linguagem e seu funcionamento: as formas do discurso. 4. ed. Campinas: Ed. Pontes, 1996.

Análise de discurso: princípios e procedimentos. Campinas: Ed. Pontes, 2007a. 
Discursos de professores em formação continuada ...

ORLANDI, E. P. As formas do silêncio. Campinas: Ed. da Unicamp, 2007b.

PEDRANCINI, V. D. et al. Ensino e aprendizagem de biologia no ensino médio e a apropriação do saber científico e biotecnológico. Revista Electrónica de Enseñanza de las Ciencias, Vigo, v. 6, n. 2, p. 299-309, 2007. Disponível em: < http://reec.uvigo.es/ volumenes/volumen6/ART5_Vol6_N2.pdf>. Acesso em: 4 jul. 2016.

PEREIRA, L. V. Seqüenciaram o genoma humano e agora? São Paulo: Moderna, 2001. PIMENTA, S. G.; GHEDIN. E. (Org.). Professor reflexivo no Brasil: gênese e crítica de um conceito. São Paulo: Cortez, 2002.

RAMOS, F. P. O conceito de gene em discursos de professores pesquisadores: evolução em andamento ou revolução permanente? 2010. 250 f. Dissertação (Mestrado em Educação para a Ciência e o Ensino de Matemática) - Universidade Estadual de Maringá, Maringá, 2010.

SCHEID, N. M. J.; FERRARI, N.; DELIZOICOV, D. A construção coletiva do conhecimento científico sobre a estrutura do DNA. Ciência \& Educação, Bauru, v. 11, n. 2, p. 223-233, 2005. Disponível em: <http://dx.doi.org/10.1590/S1516$73132005000200006>$. Acesso em: 4 jul. 2016.

SCHÖN, D. A. Educando o profissional reflexivo: um novo design para o ensino e a aprendizagem. Porto Alegre: Artmed, 2000.

SELLES, S. E.; FERREIRA, M. S. Disciplina escolar biologia: entre a retórica unificadora e as questões sociais. In: MARANDINO, M.; FERREIRA, M. S.; AMORIM, A. C. (Org.). Ensino de biologia: conhecimentos e valores em disputa. Niterói: Eduff, 2005. p. 50-62.

TIZIOTO, P. C.; ARAUJO, E. S. N. N. Fertilização in vitro e bioética nos livros didáticos. In: ARAUJO, E. S. N. N.; CALUZI, J. J.; CALDEIRA, A. M. A. (Org.). Práticas integradas para o ensino de biologia. São Paulo: Escrituras, 2008. p. 147-169.

VILAS-BOAS, A. Conceitos errôneos de genética em livros didáticos do ensino médio. Genética na Escola, Ribeirão Preto, v. 1, v. 1, p. 9-11, 2006. Disponível em: <https:// biologiaevolutiva.files.wordpress.com/2014/07/conceitos-erroneos-em-genetica.pdf6>. Acesso em: 4 jul. 2016.

XAVIER, M. C.; FREIRE A. S.; MORAES, M. O. A introdução dos conceitos de biologia molecular e biotecnologia no ensino de genética no nível médio: há espaço para a nova Biologia? In: ENCONTRO NACIONAL DE PESQUISA EM EDUCAÇÃO EM CIÊNCIAS, 5., Bauru. Atas... Bauru: ABRAPEC, 2005.

ZATZ, M. Genética: escolhas que nossos avós não faziam. São Paulo: Globo, 2011.

Artigo recebido em 28/01/2015. Aceito em 01/01/2016.

Endereço para contato: Universidade Tecnológica Federal do Paraná, Campus Santa Helena Prolongamento da Rua Cerejeira, s/n CEP 85892-000, Bairro São Luiz, Santa Helena, PR, Brasil. 